\title{
Vortex Assisted Liquid-Liquid Microextraction with Back Extraction of Repaglinide, Glibenclamide and Glimepiride in Water Samples
}

(Mikro Pengekstrakan Berbalik Cecair-Cecair Berbantu Vorteks bagi Repaglinida, Glibenclamida dan Glimepirida dalam Sampel Air)

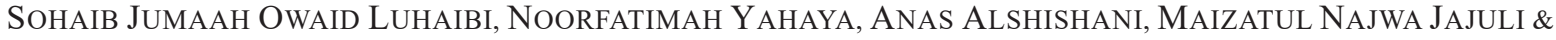 \\ MAZIDATULAKMAM MISKAM*
}

\begin{abstract}
A new analytical method based on vortex-assisted liquid-liquid microextraction with back extraction (VALLME-BE) coupled with high performance liquid chromatography was developed for the simultaneous determination of antidiabetic drugs; repaglinide, glibenclamide, and glimepiride in water samples. Chromatographic separation was achieved using C18 column $(250 \times 4.6 \mathrm{~mm} \times 5 \mu \mathrm{m})$ and methanol-phosphate buffer $(\mathrm{pH} 3.7)$ in the ratio of $70: 30 \mathrm{v} / \mathrm{v}$ as a mobile phase at a flow rate of $1 \mathrm{mLmin}^{-1}$. VALLME-BE was performed using $200 \mu \mathrm{L}$ of $n$-octane dispersed into the aqueous sample $(10 \mathrm{~mL})$ with the aid of vortexing agitation. Then, the analytes were back-extracted from the organic solvent to 0.05 $M \mathrm{NaOH}(40 \mu \mathrm{L})$. Under these conditions, enrichment factor of 155-fold was achieved. The developed VALLME-BE method showed excellent linearity in the range of 30 to $1000 \mu \mathrm{gL}^{-1}$ with limit of detection (LOD) of 0.41-1.66 $\mu \mathrm{gL} \mathrm{L}^{-1}$ and limit of quantification (LOQ) of 1.38-5.54. 41-1.66 $\mu \mathrm{gL}^{-1}$. VALLME-BE was applied for the determination of repaglinide, glibenclamide and glimepiride in water samples with the recoveries ranged from $83-109 \%$. The relative standard deviation for inter-day and intra-day precision was less than $9.9 \%$.
\end{abstract}

Keywords: Glibenclamide; glimepiride; HPLC-UV; repaglinide and vortex assisted liquid-liquid microextraction with back extraction

ABSTRAK

Suatu kaedah analitikal yang baharu berdasarkan pengekstrakan berbalik - mikro pengekstrakan cecair-cecair berbantu vorteks (VALLME-BE) digandingkan dengan kromatografi cecair berprestasi tinggi telah dibangunkan untuk penentuan serentak ubat anti-diabetik; repaglinida, glibenklamida dan glimepirida di dalam sampel air. Pemisahan kromatografi telah dicapai menggunakan turus $C 18(250 \times 4.6 \mathrm{~mm} \times 5 \mu \mathrm{m})$ dan penimbal methanol-fosfat (pH3.7) dengan nisbah 70:30 v/v sebagai fasa bergerak pada kadar aliran $1 \mathrm{mLmin}^{-1}$.VALLME-BE telah dilakukan dengan menggunakan $200 \mu \mathrm{L}$-oktana yang disebarkan ke dalam sampel akues $(10 \mathrm{~mL}$ ) dengan bantuan pengadukan. Kemudian, pengekstrakan berbalik dilakukan terhadap analit daripada pelarut organik kepada $0.05 \mathrm{M} \mathrm{NaOH}(40 \mu \mathrm{L})$. Di bawah keadaan optimum, faktor pengayaan sebanyak 155-lipat telah dicapai. Kaedah VALLME-BE yang dibangunkan telah menunjukkan kelinearan yang baik dalam julat 30 hingga $1000 \mu g L^{-1}$ dengan had pengesanan (LOD) sebanyak 0.41-1.66 $\mu g L^{-1}$ dan had pengkuantitian (LOQ) sebanyak 1.38-5.54 $\mu g L^{-1}$. VALLME-BE digunakan untuk pengekstrakan repaglinida, glibenklamida dan glimepirida dengan julat pengembalian semula adalah 83-109\%. Sisihan piawai relatif untuk inter-hari and intra-hari mempunyai kepersisan kurang daripada 9.9\%.

Kata kunci: Glibenklamida; glimepirida; HPLC-UV; repaglinida dan pengekstrakan berbalik - mikro pengekstrakan cecair-cecair berbantu vorteks

\section{INTRODUCTION}

Diabetes mellitus is one of common diseases affecting human health with 150 million people around the world are estimated sufferings from it. This is a serious public health problem, as incidence and prevalence rates are increasing worldwide (Forouhi \& Wareham 2014). Among diabetes patients, $\sim 90 \%$ of them are suffered with 
diabetes type II (non-insulin-dependent) (Siddiqui 2014). Repaglinide, glibenclamide and glimepiride are well known compounds that clinically used in the treatment of type II diabetes mellitus (T2D) (Bojarska et al. 2019; ElZaher et al. 2016). The hyperglycemia of T2D is due to inappropriately low insulin levels caused by a combination of defects in insulin secretion and action. Repaglinide is an insulin secretagogue with early onset and short duration of action that mainly targets postprandial hyperglycemia. Meanwhile, glimepiride and glibenclamide are the potent second generation oral sulfonylurea antihyperglycemic agents that increase insulin release from pancreatic beta cells (Fachi et al. 2016; Gumieniczek \& Berecka 2016).

As antidiabetic drugs are extensively used for the diabetes treatment; thus, they are continuously being released to the environment through wastewater discharges from wastewater treatment plants. The presence of pharmaceutical residues in the aquatic environment has been recognized as one of the most urgent emerging environmental issues. Toxicity of glibenclamide has been proven to have harmful effects on humans and animal species such as DNA, mutagenesis, genotoxicity, and oxidative stress (Ibarra-Costilla et al. 2010). Although the effect of repaglinide and glimepiride on environmental water still not clear, it is still important to analyse them as it is widely produced and consumed around the world.

In the last decade, several analytical methods have been developed to investigate the occurrence of the pharmaceutical compounds approved for human usage in the aquatic environment (Radke 2010; Selahle \& Nomngongo 2020). Several analytical methods have been developed for the determination of pharmaceuticals such as beta-blockers, antibiotics, anti-inflammatory drugs, antidepressants, and lipid regulators (Al-odaini et al. 2010; Kasprzyk-Hordern et al. 2007; Nannou et al. 2015). However, the methods for the analysis of antidiabetic drugs in environmental waters are scarce as the developed methods are restricted to their individual determination in biological matrices (Chen et al. 2019; Mokhtar et al. 2020; Omran et al. 2019) or in pharmaceutical preparations. At present, analytical methods reported for the determination of repaglinide, glibenclamide, and glimepiride in the aquatic environment are limited. In 2010, Lopez-Serna et al. developed online-solid phase extraction-liquid chromatography-electrospray-tandem mass spectrometry for determination of 74 pharmaceutical compounds including glibenclamide in environmental and waste waters. Glibenclamide with other compounds was extracted using Oasis MCX from environmental water sample and determined using Q-Exactive Orbitrap high resolution accurate mass spectrometry (Abdallah et al. 2019). Solid phase extraction (SPE) is widely used as sample preparation from water sample. However, SPE drawbacks are tedious and time-consuming involving multiple extraction steps. Loss of analytes can occur due to multi steps involving evaporation step prior to analysis (AbuRuz et al. 2005, 2003).

Vortex-assisted liquid-liquid microextraction with back-extraction (VALLME-BE) is a promising alternative technique to the traditional sample preparation as it is simple and cost efficient (Feng et al. 2017; Lian et al. 2014; Pizarro et al. 2014). The first step (VALLME) is the extraction of the analyte from a large amount of aqueous phase (donor phase) to small volume of organic phase (intermediate phase). In the second step, the target analyte was back-extracted from organic phase to a micro-volume of aqueous phase (acceptor phase) and this is referred as back extraction (BE). The extract can be conveniently sampled and injected directly into LC for analysis (Namieśnik et al. 2015).

Towards this end, of the plethora of microextraction techniques, the VALLME-BE seemed to be the best candidate. Thus, this paper is dedicated to the development of a VALLME-BE pretreatment method for the simultaneous determination of repaglinide, glyburide, and glimepiride in environmental water. To the best of our knowledge, the VALLME-BE method has not previously been applied for the simultaneous determination of repaglinide, glibenclamide, and glimepiride in the literature.

\section{Materials AND Methods \\ CHEMICALS AND REAGENTS}

Repaglinide, glibenclamide, and glimepiride were kindly donated by Hikma Pharmaceuticals (Amman, Jordan). Materials and reagents used were obtained from the following sources: HPLC-grade methanol (99.96\%), phosphoric acid $(85 \%, \mathrm{w} / \mathrm{w}), 1$-octanol, ethyl acetate was purchased from Merck (Darmstadt, Germany). Toluene was from Fisher Scientific (Milwaukee, WI, USA); 1-heptanol (99.9\%) and butyl acetate (99.0\%) were from Fluka (Buchs, Switzerland); sodium hydroxide (98.0\%), R\&M Marketing (Essex, UK); n-octane (99\%), Acrōs (Geel, Belgium). n-heptane (99.0\%), 1-hexanol (99\%), sodium phosphate monobasic monohydrate and sodium phosphate were obtained from Sigma-Aldrich (St. Louis, MO, USA). Ultrapure water (resistivity, 18.2 $\mathrm{M} \Omega \mathrm{cm}$ ) was produced by Millipore water purification system (Molsheim, France) and used throughout for the preparation of solutions. 


\section{HPLC CONDITIONS}

Separation was performed using Shimadzu HPLC (SPD20A) system equipped with UV Detector (LCD-20A) (Kyoto, Japan). The separations were carried out using Thermo-Fisher Hypersil Gold ODS C18 $(250 \times 4.6 \mathrm{~mm} \times$ $5 \mu \mathrm{m}$ ) (Thermo fisher Scientific Lnc., St. Wyman, Waltham, MA, USA). The mobile phase consisted of a mixture of methanol and phosphate buffer $(15 \mathrm{mM}, \mathrm{pH} 3.7)$ with ratio of $70: 30, \mathrm{v} / \mathrm{v}$. The mobile phase was filtered through $0.22 \mu \mathrm{m}$ Agilent Technologies nylon membrane filter (Waldbronn, Germany) and degassed for $20 \mathrm{~min}$ in an ultrasonic bath prior to its use. The injection volume and the flow rate were $10 \mu \mathrm{L}$ and $1 \mathrm{mLmin}^{-1}$, respectively. The detection wavelength was set at $234 \mathrm{~nm}$.

\section{PREPARATION OF STOCK AND WORKING SOLUTION}

Stock standard solutions $\left(200 \mathrm{mgL}^{-1}\right)$ of repaglinide, glibenclamide and glimepiride were prepared by dissolving the desired amounts in methanol and stored at $4{ }^{\circ} \mathrm{C}$. Working standard solutions were prepared in $10 \mathrm{~mL}$ volumetric flask by appropriate dilution of stock solution.

\section{EXTRACTION PROCEDURE FOR MICROEXTRACTION VORTEX ASSISTED LIQUID-LIQUID MICROEXTRACTION- BACK-EXTRACTION}

The extraction procedure was performed in two separate steps. Initially, a microextraction vortex assisted liquidliquid (VALLME) was performed, i.e. standard and sample solution $(10 \mathrm{~mL}) \mathrm{pH}$ was adjusted to 6.0 using $\mathrm{NaOH}$ solution $(0.1 \mathrm{M})$. Then, the sample solution was transferred into a volumetric flask $(10 \mathrm{~mL})$ and top-up the mark. Next, the solution was spiked with n-octane $(200 \mu \mathrm{L})$. The mixture was vortexed vigorously $(2500 \mathrm{rpm})$ for $60 \mathrm{~s}$ to from fine droplets using a vortex agitator. The mixture was left for $\sim 1 \mathrm{~min}$ to reform the n-octane single drop. The organic phase was collected and then transferred to centrifuged tube $(1.5 \mu \mathrm{L})$ using micropipette. Thereafter, a back extraction (BE) procedure was performed by the addition of $40 \mu \mathrm{L} \mathrm{NaOH}$ solution $(0.05 \mathrm{M})$. The mixture was again vortexed $(1500 \mathrm{rpm})$ for $1 \mathrm{~min}$ then centrifuged (4000 rpm) for $1 \mathrm{~min}$. Finally, $10 \mu \mathrm{L}$ from the bottom aqueous drop was carefully withdrawn using a microsyringe and directly injected into HPLC.

\section{METHOD VALIDATION}

The validation parameters of the proposed methods such as linearity, limits of detection (LOD), limits of quantitation (LOQ), repeatability, and recovery were tested after subjecting the working standards to the VALLME-BE procedure. Individual analyte was assessed for linearity using five-point calibration curve over the range $30-1000$ $\mu \mathrm{gL}^{-1}$. The calibration curve was plotted, and the slope and $y$-intercept of the curve was determined with linear regression.

\section{REAL SAMPLE ANALYSIS}

Six water samples (sea and river water) were collected at different places around Pulau Pinang, Malaysia to study the applicability of the proposed VALLME-BE procedure. After sampling, all samples were stored at $4{ }^{\circ} \mathrm{C}$ in the dark until use. Prior to the extraction, the water samples filtered through $0.45 \mu \mathrm{m}$ membrane filters to remove impurities. Repeatability was investigated by injecting six replicates of three different concentrations levels of 30,500 , and $1000 \mu \mathrm{gL}^{-1}$ and was expressed as relative standard deviation (\%RSD). Accuracy was determined by evaluating the recovery of the analyte at low, medium and high concentration levels. The samples were spiked at three levels concentration $\left(30,500\right.$, and $\left.1000 \mu \mathrm{gL}^{-1}\right)$.

\section{RESULTS AND DISCUSSION}

\section{OPTIMIZATION OF VALLME-BE PARAMETERS} TYPE AND VOLUME OF THE INTERMEDIATE PHASE

The selection of solvent as intermediate phase (IP) should be based on its ability to form good emulsion after vortexing and possess a higher density as compared to water to reformed on the bottom of the tube which facilitate the transfer of such small extraction phase (Çabuk \& Köktürk 2013). Seven extraction solvents including heptanol, hexanol, octanol, butyl acetate, octane, heptane, and hexane were tested for the extraction based on their polarities and interaction with analytes.

Figure 1(a) shows the effect of different types of solvents on the enrichment factor (EF) of repaglinide, glibenclamide, and glimepiride. Alcoholic solvents such as 1-hexanol, 1-heptanol and 1-octanol and ester, butyl acetate showed the lowest extraction efficiency among the selected solvents. This is due to the low affinity of analyte to these solvents which affected the mass transfer of analyte from donor phase into intermediate phase (Ho et al. 2004). Amongst n-alkane groups, octane exhibited the highest extraction efficiency due to its high solvation factor and high back extraction efficiency to acceptor phase. The analyte was also a lipophilic and non-polar compound. Hence, its interaction with non- 
polar solvent gives the highest EF. Another factor is the volume of reformed layer, because octane reformed a higher layer volume than heptanol and hexane according to their polarity. Therefore, octane was selected for further optimization studies.
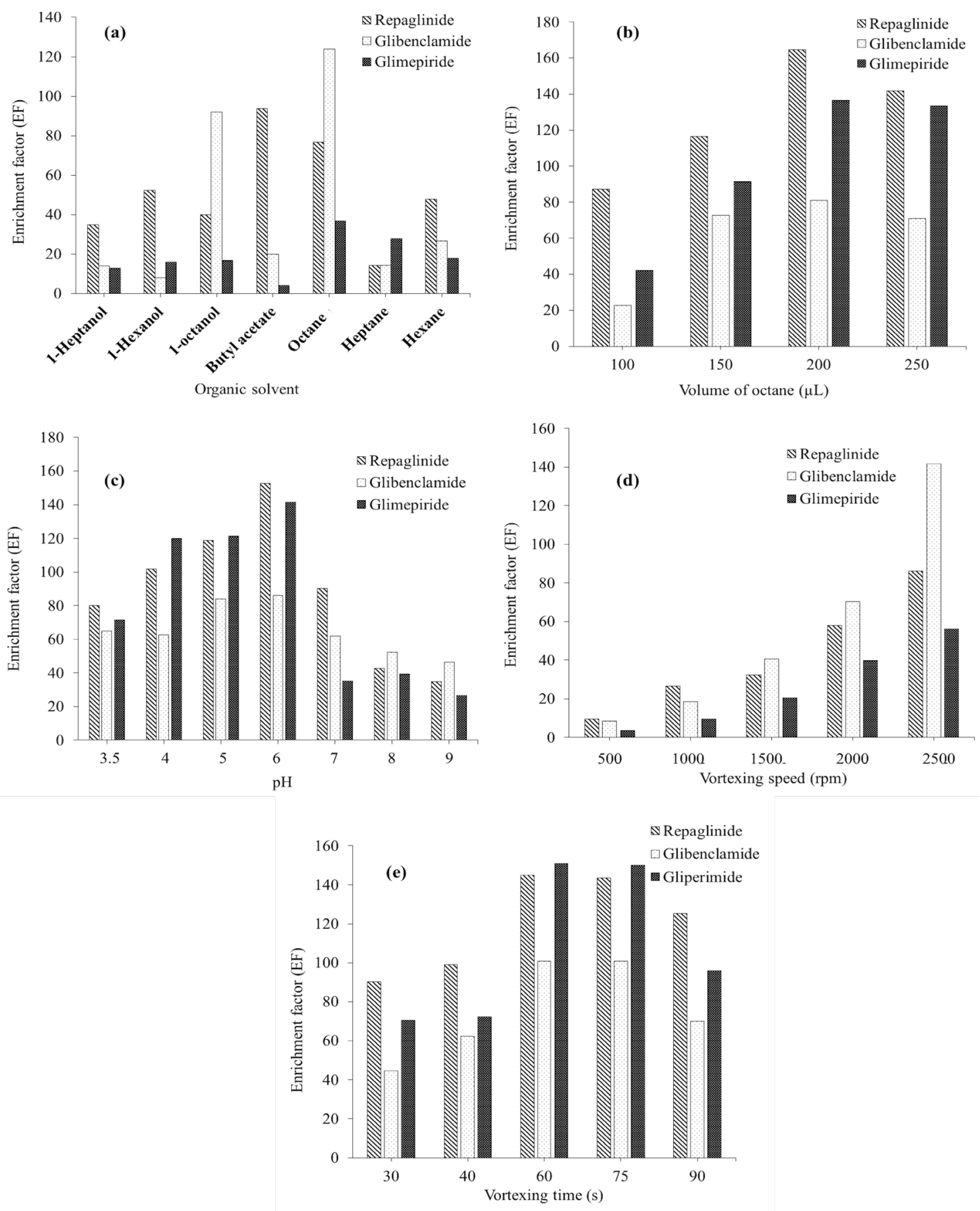

FIGURE 1. Effect of (a) extraction solvent (b) volume of extraction solvent (c) $\mathrm{pH}$ (d) vortexing speed and (e) vortexing time on the enrichment factor of repaglinide, glibenclamide and glimepiride. MSPE conditions: repaglinide, glibenclamide and glimepiride concentration: $1 \mathrm{mgL}^{-1}$, desorption eluent: $\mathrm{NaOH} 0.05 \mathrm{M}$, volume of eluent: $40 \mathrm{~mL}$, vortex at $1500 \mathrm{rpm}$ for $60 \mathrm{~s}$ 
The volume of extraction solvent influences the ratio of analyte between donor phase/intermediate phase (DP/ IP) and intermediate phase/acceptor phase (IP/AP) as it affects the equilibrium and the transfer rates of the analyte between both phases. Furthermore, the selection of suitable ratio was very important because it improves the partitioning of the analyte between the two immiscible phases (Makahleh et al. 2015). In this study, different volumes of n-octane in the range from $100-250 \mu \mathrm{L}$ were used. Based on the result depicted in Figure 1(b), the $\mathrm{EF}$ increased as the volume of n-octane increased up to $250 \mu \mathrm{L}$ and dropped thereafter. This might be due to the dilution factor which reduced the mass transfer of analyte in intermediate phase to the acceptor phase. Therefore, 200 $\mu \mathrm{L}$ of octane was selected for further analysis.

\section{pH OF DONOR PHASE}

The suitable $\mathrm{pH}$ of donor phase is a key factor to ensure analytes are transfer into organic solvent (intermediate phase). As depicted in Figure 1(c), the $\mathrm{pH}$ range was studied from $\mathrm{pH} 3.50$ to 9 . Based on the data obtained, the enrichment factor increased as the $\mathrm{pH}$ increased from 4 to 5 and dropped after $\mathrm{pH} 6$.

Two of the analytes are basic (glibenclamide and glimepiride) and the expected $\mathrm{pH}$ that suppress the ionization should be higher than the $\mathrm{p} K_{\mathrm{a}}$, so it should be higher than 5. Meanwhile, repaglinide contains both acidic and basic functional group which make the predication of the $\mathrm{pH}$ not easy. According to the moderately high molecule size of the analytes; the ionization of the basic and acidic functional groups (which affected by $\mathrm{pH}$ ) could not be the major driving force for the extraction, instead the hydrophobicity (the $\log P$ of the analyte is relatively high) of the molecule could be the main driving force which could justify the non-rational results of the enrichment factor in $\mathrm{pH}$ study. Therefore, $\mathrm{pH} 6$ was selected as optimum $\mathrm{pH}$ for subsequent analysis.

\section{VORTEX SPEED AND TIME}

A vortex agitator was used to swirl the two immiscible liquid phases and create vortex emulsification between both phases. Furthermore, vortexing the immiscible phase during the extraction and back-extraction is essential in order to form fine droplets. Thus, the contact surface area was increased and further enhanced the mass transfer of the analyte (Yiantzi et al. 2010). The vortex speed range was studied from 1000 to maximum speed of $2500 \mathrm{rpm}$. It was observed that the extraction efficiency increased with the increased of the vortexing speed. The enhancement in the emulsification process broke down the single drop into smaller droplets has resulted in the increasing of the specific surface area and the mass transfer of repaglinide, glibenclamide, and glimepiride. As shown in Figure 1(d), the highest extraction efficiency achieved at the maximum vortexing speed at $2500 \mathrm{rpm}$. Hence, that maximum speed was chosen for the subsequent study.

Vortexing time is another important parameter which influences the emulsification process and affects the equilibrium between the donor phase and intermediate phase and also the mass transfer of the analyte. Different durations from 30 to $120 \mathrm{~s}$ of vortex agitation were studied in VALLME procedure. Based on the results in Figure 1(e), it was found that the extraction efficiency was improved as the analyte was extracted from aqueous phase into organic phase and whenever vortexing time increased, the analyte was back extracted into donor phase. Therefore, $60 \mathrm{~s}$ was selected in vortexing time for further study.

\section{ACCEPTOR PHASE CONCENTRATION AND VOLUME}

In the second step, the anti-diabetic drugs were backextracted from the octane into the $\mathrm{NaOH}$ as the acceptor phase (aqueous phase, AP). The analytes should be in the ionized form in the acceptor phase to avoid the back-extraction in octane (Alshishani et al. 2016). Repaglinide, glibenclamide, and glimepiride is a basic compound attributed to an amine group. They are existing predominantly in an ionized form at lower $\mathrm{pH}$. Therefore, in order to find suitable $\mathrm{pH}$ medium, sodium hydroxide $(\mathrm{NaOH})$ was selected as acceptor phase. The effect of $\mathrm{NaOH}$ concentration was studied in the range of $0.025-$ $0.100 \mathrm{M}$. Referring to Figure 2(a), the extraction efficiency was increased as the concentration of $\mathrm{NaOH}$ increased and the concentration of $0.05 \mathrm{M} \mathrm{NaOH}$ gave the highest extraction efficiency. Hence, $0.05 \mathrm{M} \mathrm{NaOH}$ was selected for further studies. The concentration of $\mathrm{NaOH}$ above 0.1 $M$ was neglected due to the corrosion effect on the injector and other parts of HPLC (Makahleh et al. 2015).

The volume of acceptor phase should also be carefully selected in order to find the optimum volume for high recovery and avoid to the dilution of target analytes. The volume is directly associated with mass transfer of target analytes from the intermediate phase to the accepter phase. The range effect of volume $(15-40 \mu \mathrm{L})$ of accepter phase was investigated. The EF was presented 
in Figure 2(b). The volume less than $20 \mu \mathrm{L}$ were not considered as it is insufficient for the HPLC analysis. The enrichment factor increased when the volume of
$\mathrm{NaOH}$ increased until $40 \mu \mathrm{L}$ then dropped thereafter. The increment may be due to sufficient volume of $\mathrm{NaOH}$ to extract the targeted analytes in the intermediate phases.
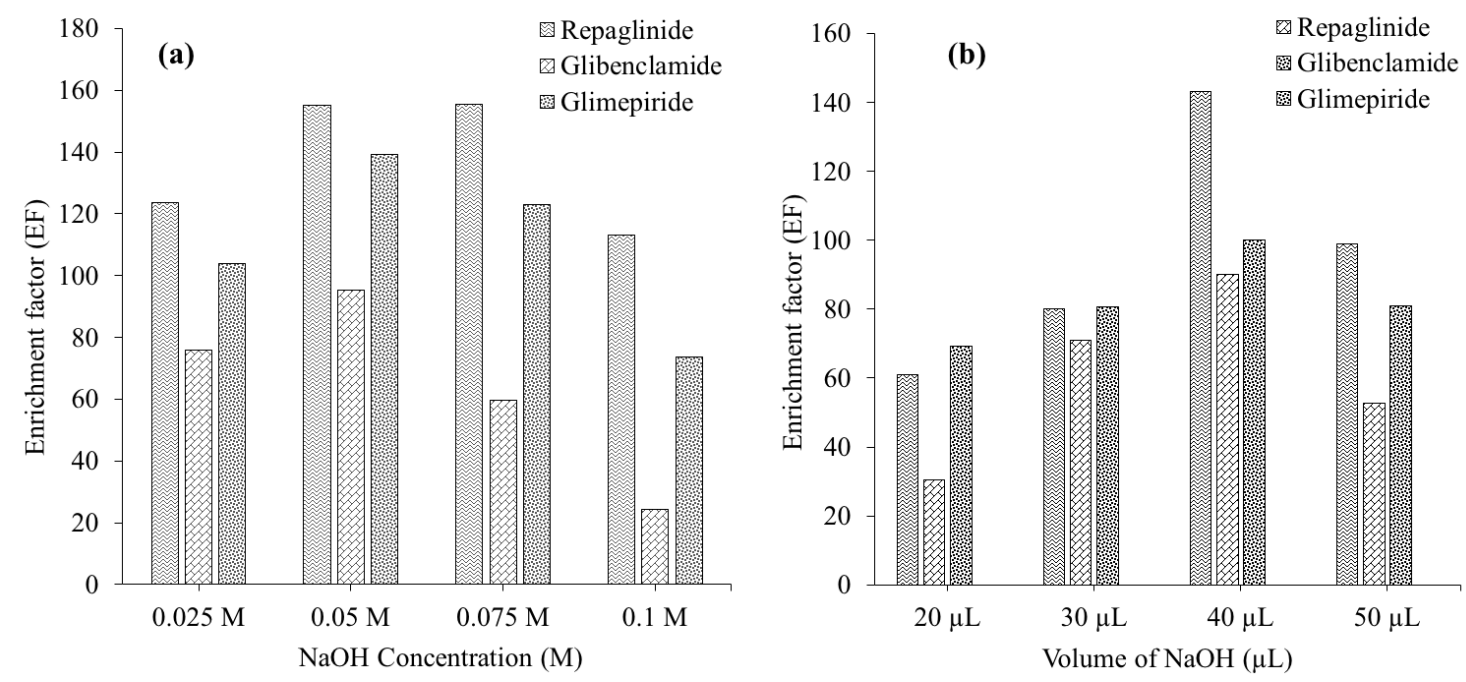

FIGURE 2. Effect of (a) NaOH concentration and (b) $\mathrm{NaOH}$ volume, on enrichment factor of repaglinide, glibenclamide, and glimepiride. Experimental conditions, adsorption: Repaglinide, glibenclamide and glimepiride concentration; $1 \mathrm{mgL}^{-1}$ adjusted to $\mathrm{pH} 6$, volume of octane; $200 \mu \mathrm{L}$, the $\mathrm{pH}$ 6, vortexing speed; $2500 \mathrm{rpm}$ for $1 \mathrm{~min}$. Desorption conditions: vortex at $1500 \mathrm{rpm}$ for $60 \mathrm{~s}$

The decreased in EF at $50 \mu \mathrm{L}$ could be justified by decrease of drugs final concentration in the $\mathrm{NaOH}$ phase due to dilution factor. Thus, $40 \mu \mathrm{L}$ was selected for the subsequent experiments.

\section{METHOD VALIDATION}

Under the optimized experimental conditions, VALLMEBE method showed good linearity in the calibration range of $30-1000 \mu \mathrm{gL}^{-1}$, with coefficient of determination $\left(\mathrm{R}^{2}\right)$ of $0.9985,0.9966$, and 0.9987 for repaglinide, glibenclamide, and glimepiride, respectively. The limit of detection (LOD) for the extraction of repaglinide, glibenclamide, and glimepiride were found to be in the range of 0.41-1.66 $\mu \mathrm{gL}^{-1}$ and limit of quantification (LOQ) were $1.38-5.54 \mu \mathrm{gL}^{-1}$, respectively. Table 1 summarizes the analytical performance of the established method. 
TABLE 1. Method validation for the proposed VALLME-BE method

\begin{tabular}{lcccc}
\hline & $\begin{array}{c}\text { Linearity range } \\
\left(\mu \mathrm{gL}^{-1}\right)\end{array}$ & $\mathrm{r}^{2}$ & $\begin{array}{c}\text { LOD } \\
\left(\mu \mathrm{gL}^{-1}\right)\end{array}$ & $\begin{array}{c}\text { LOQ } \\
\left(\mu \mathrm{gL}^{-1}\right)\end{array}$ \\
\hline Repaglinide & $30-1000$ & 0.9985 & 0.41 & 1.38 \\
Glibenclamide & $30-1000$ & 0.9966 & 1.04 & 3.45 \\
Glimepiride & $30-1000$ & 0.9987 & 1.66 & 5.54 \\
\hline
\end{tabular}

\section{ANALYTICAL APPLICATION ON REAL SAMPLES}

In order to evaluate the accuracy and applicability, the proposed extraction method was applied in environmental samples for the determination of repaglinide, glibenclamide, and glimepiride. All unspiked water samples showed no trace of repaglinide, glibenclamide, and glimepiride. The chromatograms of selected river and seawater were depicted in Figure 3.
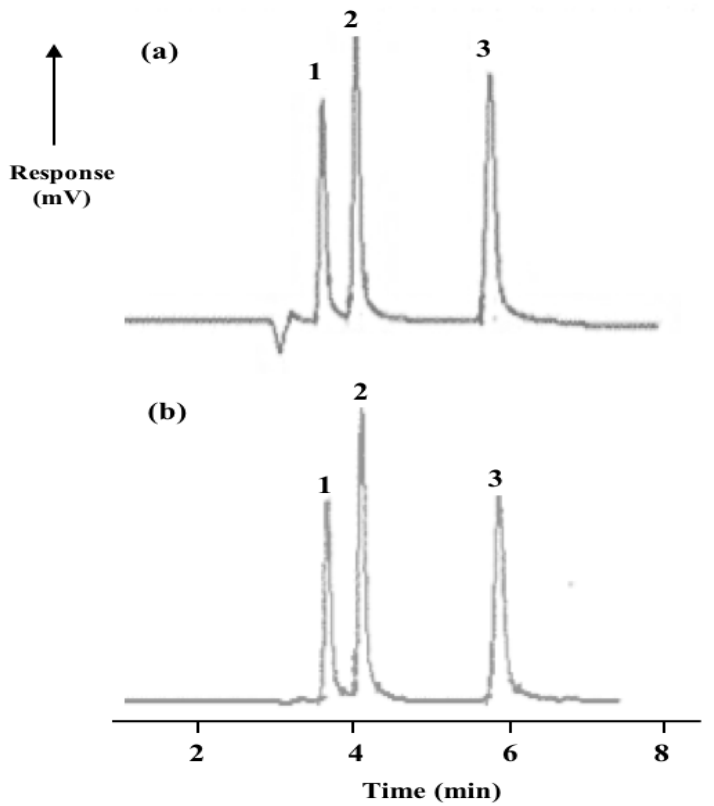

FIGURE 3. HPLC chromatograms of antidiabetic drugs subjected to VALLME$\mathrm{BE}$ (a) spiked river $\left(30 \mathrm{mgL}^{-1}\right)$ and (b) spiked sea water $\left(30 \mathrm{mgL}^{-1}\right)$ under the optimized extraction conditions, (1) repaglinide, (2) glibenclamide and (3) glimepiride. Column; Thermo-Fisher Hypersil Gold ODS C18 $(250 \times 4.6 \mathrm{~mm}$ $\times 5 \mu \mathrm{m})$, mobile phase; methanol and phosphate buffer $(15 \mathrm{mM}, \mathrm{pH} 3.7), \lambda$; $234 \mathrm{~nm}$, flow rate; $1 \mathrm{mLmin}^{-1}$ 
The analytical results along with the recoveries for the spiked samples with known concentration $(30,500$, $\left.1000 \mu \mathrm{gL}^{-1}\right)$ are listed in Table 2. The recoveries were acceptable (83.4 - 109.0\%). The precision of the analytical procedure was determined using six replicates samples. The repeatability obtained was good (below $15 \%$ ). It was found that the precision ( $\% \mathrm{RSD})$ for three concentration levels $\left(30,500\right.$, and $\left.1000 \mu \mathrm{gL}^{-1}\right)$ was less than $9.5 \%$.

TABLE 2. Recoveries and precision obtained by spiking river and seawater

\begin{tabular}{|c|c|c|c|c|c|c|c|c|c|c|}
\hline \multirow{3}{*}{\multicolumn{2}{|c|}{$\begin{array}{c}C \text { added } \\
\left(\mu \mathrm{gL}^{-1}\right)\end{array}$}} & \multirow{2}{*}{\multicolumn{3}{|c|}{ Recovery $(\% \mathrm{X} \pm \mathrm{SD})$}} & \multicolumn{6}{|c|}{ Precision (\%RSD) } \\
\hline & & & & & \multirow[b]{2}{*}{ REPA } & \multicolumn{2}{|c|}{ nter-day } & \multicolumn{3}{|c|}{ Intra-day } \\
\hline & & REPA & GLIB & GLIM & & GLIB & GLIM & REPA & GLIB & GLIM \\
\hline River $^{\mathrm{a}}$ & $\begin{array}{l}30 \\
500 \\
1000\end{array}$ & $\begin{array}{c}89.2 \pm 6.1 \\
101.6 \pm 2.1 \\
94.1 \pm 3.1\end{array}$ & $\begin{array}{c}97.4 \pm 7.1 \\
109.0 \pm 6.1 \\
100.0 \pm 9.1\end{array}$ & $\begin{array}{l}98.9 \pm 2.1 \\
87.5 \pm 5.1 \\
83.4 \pm 5.1\end{array}$ & $\begin{array}{l}4.8 \\
5.4 \\
6.2\end{array}$ & $\begin{array}{l}6.7 \\
2.4 \\
7.2\end{array}$ & $\begin{array}{l}7.5 \\
3.9 \\
4.5\end{array}$ & $\begin{array}{l}4.3 \\
3.1 \\
7.7\end{array}$ & $\begin{array}{l}5.1 \\
4.8 \\
3.5\end{array}$ & $\begin{array}{l}6.1 \\
5.5 \\
8.9\end{array}$ \\
\hline Seawater ${ }^{\mathrm{b}}$ & $\begin{array}{l}30 \\
500 \\
1000\end{array}$ & $\begin{array}{c}98.1 \pm 9.1 \\
105 \pm 1.9 \\
109 \pm 2.7\end{array}$ & $\begin{array}{c}89.9 \pm 7.1 \\
100.1 \pm 6.7 \\
109.0 \pm 1.6\end{array}$ & $\begin{array}{l}90.6 \pm 1.2 \\
87.9 \pm 3.0 \\
91.2 \pm 2.6\end{array}$ & $\begin{array}{l}6.6 \\
4.5 \\
2.3\end{array}$ & $\begin{array}{l}2.9 \\
6.4 \\
3.2\end{array}$ & $\begin{array}{l}7.5 \\
4.9 \\
2.5\end{array}$ & $\begin{array}{l}3.3 \\
3.1 \\
3.7\end{array}$ & $\begin{array}{l}8.1 \\
6.8 \\
1.5\end{array}$ & $\begin{array}{l}5.1 \\
4.5 \\
4.9\end{array}$ \\
\hline Seawater & $\begin{array}{l}30 \\
500 \\
1000\end{array}$ & $\begin{array}{c}103.9 \pm 5.9 \\
96.9 \pm 6.1 \\
99.1 \pm 8.1\end{array}$ & $\begin{array}{c}107.9 \pm 6.9 \\
100.9 \pm 1.5 \\
87.3 \pm 9.1\end{array}$ & $\begin{array}{c}90.0 \pm 3.8 \\
104.6 \pm 7.1 \\
107 \pm 4.5\end{array}$ & $\begin{array}{l}6.8 \\
5.4 \\
3.2\end{array}$ & $\begin{array}{l}8.7 \\
6.4 \\
5.2\end{array}$ & $\begin{array}{l}4.5 \\
9.9 \\
7.5\end{array}$ & $\begin{array}{l}7.3 \\
6.1 \\
4.7\end{array}$ & $\begin{array}{l}5.1 \\
5.8 \\
8.5\end{array}$ & $\begin{array}{l}4.6 \\
6.5 \\
4.9\end{array}$ \\
\hline Seawater ${ }^{d}$ & $\begin{array}{l}30 \\
500 \\
1000\end{array}$ & $\begin{array}{c}88.7 \pm 7.5 \\
88.3 \pm 5.1 \\
102.9 \pm 7.5\end{array}$ & $\begin{array}{c}97.4 \pm 4.1 \\
100.3 \pm 3.1 \\
99.8 \pm 9.1\end{array}$ & $\begin{array}{c}106.9 \pm 6.6 \\
90.1 \pm 3.9 \\
109.0 \pm 1.1\end{array}$ & $\begin{array}{l}7.8 \\
5.7 \\
3.2\end{array}$ & $\begin{array}{l}4.7 \\
2.4 \\
6.2\end{array}$ & $\begin{array}{l}8.5 \\
5.9 \\
7.5\end{array}$ & $\begin{array}{l}6.9 \\
7.1 \\
4.7\end{array}$ & $\begin{array}{l}5.9 \\
4.8 \\
8.5\end{array}$ & $\begin{array}{l}8.1 \\
5.5 \\
4.9\end{array}$ \\
\hline Seawater ${ }^{\mathrm{e}}$ & $\begin{array}{l}30 \\
500 \\
1000\end{array}$ & $\begin{array}{c}99.0 \pm 5.1 \\
103.9 \pm 9.1 \\
104.7 \pm 2.1\end{array}$ & $\begin{array}{l}87.9 \pm 5.2 \\
92.2 \pm 3.1 \\
84.0 \pm 6.9\end{array}$ & $\begin{array}{c}104.6 \pm 4.1 \\
98.7 \pm 6.9 \\
100.1 \pm 2.1\end{array}$ & $\begin{array}{l}7.8 \\
8.8 \\
4.2\end{array}$ & $\begin{array}{l}3.7 \\
3.4 \\
3.2\end{array}$ & $\begin{array}{l}7.5 \\
8.9 \\
3.8\end{array}$ & $\begin{array}{l}5.3 \\
3.1 \\
4.7\end{array}$ & $\begin{array}{l}3.9 \\
7.8 \\
3.5\end{array}$ & $\begin{array}{l}8.1 \\
4.5 \\
5.1\end{array}$ \\
\hline Seawater ${ }^{\mathrm{f}}$ & $\begin{array}{l}30 \\
500 \\
1000\end{array}$ & $\begin{array}{c}99.9 \pm 6.1 \\
83.3 \pm 7.7 \\
109.0 \pm 6.9\end{array}$ & $\begin{array}{c}93.0 \pm 1.3 \\
87.2 \pm 3.3 \\
95.0 \pm 10.9\end{array}$ & $\begin{array}{c}100.7 \pm 3.0 \\
109.0 \pm 2.7 \\
98.4 \pm 6.1\end{array}$ & $\begin{array}{l}4.8 \\
3.4 \\
9.2\end{array}$ & $\begin{array}{l}5.3 \\
9.2 \\
7.2\end{array}$ & $\begin{array}{l}6.9 \\
3.1 \\
9.5\end{array}$ & $\begin{array}{l}6.7 \\
4.4 \\
5.9\end{array}$ & $\begin{array}{l}9.5 \\
7.9 \\
9.4\end{array}$ & $\begin{array}{l}6.9 \\
4.6 \\
6.2\end{array}$ \\
\hline
\end{tabular}

REPA; repaglinide, GLIB; glibenclamide, GLIM; glimepiride

River water: a: Sungai Dua, Penang. Seawater: b: Bayan Lepas, Penang, c: Batu Ferringhi, Penang, d: Batu Maung, Penang, e: Padang Kota, Penang, f: Tanjung Bungah, Penang

\section{COMPARISON TO PREVIOUSLY REPORTED METHODS}

The performance of the developed VALLME-BE has been reviewed by a comparison with other reported preconcentration techniques for the extraction of repaglinide, glibenclamide, and glimepiride in literature, as summarised in Table 3. It was evident that the proposed method in the current work produced acceptable recoveries and in the range with other methods. The
LOD and LOQ of the developed VALLME-BE was higher than the reported methods due to the different in instrumentation. However, most reported method require evaporation which is time-consuming unlike the proposed method. Moreover, the developed VALLME-BE method utilised low consumption of organic solvents as compared to other methods. The proposed method was a simple, low solvent consumption and rapid for the determination 
of repaglinide, glibenclamide and glimepiride in water samples.

\section{CONCLUSION}

An interesting new analytical method has been developed for the HPLC-UV determination of antidiabetic drugs based on VALLME-BE. The proposed procedure combined sample clean and preconcentration into two steps (VALLME and BE) for the first time reported for the determination of repaglinide, glibenclamide, and glimepiride and the final extract can be directly injected for to the analysis into the HPLC column. The developed VALLME-BE method displays advantages such as simple, rapid, low cost, quickness, satisfactory sensitivity and environmental friendliness hence, it can be employed for a significant potential for extraction and the determination of these drugs.

TABLE 3. Comparison between the VALLME-BE and some reported method for the determination of REP, GLIB and GLIM in water sample

\begin{tabular}{|c|c|c|c|c|c|c|c|}
\hline Analytes & $\begin{array}{l}\text { Sample } \\
\text { type }\end{array}$ & $\begin{array}{l}\text { Extraction } \\
\text { technique }\end{array}$ & Instrumentation & $\operatorname{LOD}\left(\mu \mathrm{gL}^{-1}\right)$ & $\operatorname{LOQ}\left(\mu \mathrm{gL}^{-1}\right)$ & $\begin{array}{l}\text { Recovery } \\
(\%)\end{array}$ & Ref. \\
\hline $\begin{array}{l}\text { GLIB and } 80 \\
\text { pharmaceutical } \\
\text { compounds }\end{array}$ & $\begin{array}{l}\text { Surface } \\
\text { water }\end{array}$ & SPE & $\begin{array}{l}\text { UPLC-QqLIT- } \\
\text { MS }\end{array}$ & $\begin{array}{l}0.0005- \\
0.0037\end{array}$ & $0.0017-0.0125$ & - & (Gros et al. 2012) \\
\hline $\begin{array}{l}\text { REP } \\
\text { GLIB } \\
\text { and } 154 \\
\text { polar organic } \\
\text { chemical } \\
\text { contaminants }\end{array}$ & Wastewater & SPE & LC-MS-MS & - & $\begin{array}{l}0.0005 \\
0.0100\end{array}$ & - & (Loos et al. 2013) \\
\hline $\begin{array}{l}\text { MET } \\
\text { GLIB } \\
\text { VIL } \\
\text { SIT } \\
\text { PIO }\end{array}$ & $\begin{array}{l}\text { Waste water } \\
\text { River water } \\
\text { Tap water }\end{array}$ & SPE & $\begin{array}{l}\text { HPLC-QToF- } \\
\text { MS }\end{array}$ & - & $\begin{array}{l}0.0082-0.032 \\
0.0039-0.043 \\
0.0004-0.0006 \\
0.0031-0.0032 \\
0.0011-0.0012\end{array}$ & $\begin{array}{l}28-54 \\
73-81 \\
60-91 \\
79-84 \\
82-84\end{array}$ & $\begin{array}{l}\text { (Martín et al. } \\
\text { 2012) }\end{array}$ \\
\hline REP & $\begin{array}{l}\text { Milli } \\
\text { Q-water } \\
\text { Surface } \\
\text { water } \\
\text { Waste water }\end{array}$ & SPE & LC-MS-MS & - & $\begin{array}{l}0.56 \\
0.52 \\
0.48\end{array}$ & $\begin{array}{l}89 \\
113-117 \\
96-112\end{array}$ & $\begin{array}{l}\text { (Grabic et al. } \\
2012 \text { ) }\end{array}$ \\
\hline GLIB & $\begin{array}{l}\text { Effluent and } \\
\text { surface } \\
\text { water } \\
\text { samples }\end{array}$ & SPE & $\begin{array}{l}\text { UPLC-Q } \\
\text { Exactive } \\
\text { Orbitrap-HRMS }\end{array}$ & 0.30 & 0.99 & 88.3 & $\begin{array}{l}\text { (Abdallah et al. } \\
\text { 2019) }\end{array}$ \\
\hline $\begin{array}{l}\text { REP } \\
\text { GLIB } \\
\text { GLIM }\end{array}$ & $\begin{array}{l}\text { Seawater } \\
\text { and } \\
\text { River water }\end{array}$ & $\begin{array}{l}\text { VALLME- } \\
\text { BE }\end{array}$ & HPLC-UV & $\begin{array}{l}0.41 \\
1.04 \\
1.66\end{array}$ & $\begin{array}{l}1.38 \\
3.45 \\
5.54\end{array}$ & $\begin{array}{l}83.3-109.0 \\
84-109.0 \\
83.4-109.0\end{array}$ & This work \\
\hline
\end{tabular}

SPE: Solid phase extraction, UPLC: Ultra performance liquid chromatography, QqLIT: Quadrupole linear ion trap, MS: Mass spectrometry, REP: repaglinide, GLIB: glibenclamide, GLIM: glimepiride, VIL: Vildagliptin, SIT: Sitagliptin, PIO: Pioglitazone, HPLC: High performance liquid chromatography, QToF: Quadrupole time of flight, UV: Ultra-violet 


\section{ACKNOWLEDGEMENTS}

The authors were grateful for the Fundamental Research Grant Scheme (FRGS) from the Ministry of Higher Education, Malaysia (FRGS/203/PKIMIA/6711924).

\section{REFERENCES}

Abdallah, M.A., Nguyen, K., Ebele, A.J., Atia, N.N., Ali, H.R.H. \& Harrad, S. 2019. A single run, rapid polarity switching method for determination of 30 pharmaceuticals and personal care products in waste water using q-exactive orbitrap high resolution accurate mass spectrometry. Journal of Chromatography A 1588: 68-76.

AbuRuz, S., Millership, J. \& McElnay, J. 2005. The development and validation of liquid chromatography method for the simultaneous determination of metformin and glipizide, gliclazide, glibenclamide or glimperide in plasma. Journal of Chromatography B: Analytical Technologies in the Biomedical and Life Sciences 817(2): 277-286.

AbuRuz, S., Millership, J. \& McElnay, J. 2003. Determination of metformin in plasma using a new ion pair solid phase extraction technique and ion pair liquid chromatography. Journal of Chromatography B 798(2): 203-209.

Al-Odaini, N.A., Zakaria, M.P., Yaziz, M.I. \& Surif, S. 2010. Multi-Residue analytical method for human pharmaceuticals and synthetic hormones in river water and sewage effluents by solid-phase extraction and liquid chromatography - tandem mass spectrometry. Journal of Chromatography A 1217(44): 6791-6806.

Alshishani, A., Makahleh, A., Yap, H.F., Gubartallah, E.A., Salhimi, S.M. \& Saad, B. 2016. Ion-pair vortex assisted liquid-liquid microextraction with back extraction coupled with high performance liquid chromatography-UV for the determination of metformin in plasma. Talanta 161: 398404.

Bojarska, J., Fruziński, A., Sieroń, L. \& Maniukiewicz, W. 2019. The first insight into the supramolecular structures of popular drug repaglinide: Focus on intermolecular interactions in antidiabetic agents. Journal of Molecular Structure 1179: 411-420.

Çabuk, H. \& Köktürk, M. 2013. Low density solventbased dispersive liquid-liquid microextraction for the determination of synthetic antioxidants in beverages by high-performance liquid chromatography. The Scientific World Journal 2013: 1-8.

Chen, L., Xiu, R., Wang, H., Wang, L., Wu, G., Liang, J. \& Han, X. 2019. Simultaneous quantification of ten oxysterols based on LC-MS/MS and its application in atherosclerosis human serum samples. Chromatographia 82(2): 553-564.

El-Zaher, A.A., Elkady, E.F., Elwy, H.M. \& Saleh, M.A. 2016. Simultaneous determination of metformin, glipizide, repaglinide, and glimepiride or metformin and pioglitazone by a validated LC method: Application in the presence of metformin impurity (1-cyanoguanidine). Journal of AOAC International 99(4): 957-963.
Fachi, M.M., Cerqueira, L.B., Leonart, L.P., De Francisco, T.M.G. \& Pontarolo, R. 2016. Simultaneous quantification of antidiabetic agents in human plasma by a UPLC-QToF-MS method. PLoS ONE 11(12): 1-17.

Feng, T., Xu, X., Du, M., Tan, M., Qin, L. \& Zhu, B. 2017. Simultaneous determination of glyoxal, methylglyoxal and diacetyl in beverages using vortex-assisted liquid-liquid microextraction coupled with HPLC-DAD. Analytical Methods 9(16): 2445-2451.

Forouhi, N.G. \& Wareham, N.J. 2014. Epidemiology of diabetes. Medicine (Abingdon) 42(12): 698-702.

Grabic, R., Fick, J., Lindberg, R.H., Fedorova, G. \& Tysklind, M. 2012. Multi-residue method for trace level determination of pharmaceuticals in environmental samples using liquid chromatography coupled to triple quadrupole mass spectrometry. Talanta 100: 183-195.

Gros, M., Rodríguez-Mozaz, S. \& Barceló, D. 2012. Fast and comprehensive multi-residue analysis of a broad range of human and veterinary pharmaceuticals and some of their metabolites in surface and treated waters by ultra-highperformance liquid chromatography coupled to quadrupolelinear ion trap tandem. Journal of Chromatography A 1248: 104-121.

Gumieniczek, A. \& Berecka, A. 2016. Analytical tools for determination of new oral antidiabetic drugs, glitazones, gliptins, gliflozins and glinides, in bulk materials, pharmaceuticals and biological samples. Open Chemistry 14(1): 215-242.

Ho, E.N.M., Yiu, K.C.H., Wan, T.S.M., Stewart, B.D. \& Watkins, K.L. 2004. Detection of anti-diabetics in equine plasma and urine by liquid chromatography-tandem mass spectrometry. Journal of Chromatography B: Analytical Technologies in the Biomedical and Life Sciences 811(1): 65-73.

Ibarra-Costilla, E., Cerda-Flores, R.M., Dávila-Rodríguez, M.I., Samayo-Reyes, A., Calzado-Flores, C. \& CortésGutiérrez, E.I. 2010. DNA damage evaluated by comet assay in mexican patients with type 2 diabetes mellitus. Acta Diabetologica 47(1): 111-116.

Kasprzyk-Hordern, B., Dinsdale, R.M. \& Guwy, A.J. 2007. Multi-residue method for the determination of basic/ neutral pharmaceuticals and illicit drugs in surface water by solid-phase extraction and ultra performance liquid chromatography - positive electrospray ionisation tandem mass spectrometry. Journal of Chromatography A 1161(12): $132-145$.

Lian, Y., Qiu, X. \& Yang, Y. 2014. Vortex-assisted liquid-liquid microextraction combined with hplc for the simultaneous determination of five phthalate esters in liquor samples. Food Analytical Methods 7(3): 636-644.

Loos, R., Carvalho, R., António, D.C., Comero, S., Locoro, G., Tavazzi, S., Ghiani, B.P.M., Lettieri, T., Blaha, L., Jarosova, B., Voorspoels, S., Servaes, K., Haglund, P., Fick, J., Lindberg, R.H., Schwesig, D. \& Gawlik, B.M. 2013. EU-wide monitoring survey on emerging polar organic contaminants in wastewater treatment plant effluents. Water Research 47(17): 6475-6487. 
López-serna, R., Pérez, S., Ginebreda, A., Petrovi, M. \& Barceló, D. 2010. Fully automated determination of 74 pharmaceuticals in environmental and waste waters by online solid phase extraction - liquid chromatography-electrospray - tandem mass spectrometry. Talanta 83(2): 410-424.

Makahleh, A., Yap, H.F. \& Saad, B. 2015. Vortex-assisted liquid-liquid-liquid microextraction (VALLLME) technique: A new microextraction approach for direct liquid chromatography and capillary electrophoresis analysis. Talanta 143: 394-401.

Martín, J., Buchberger, W., Santos, J.L., Alonso, E. \& Aparicio, I. 2012. High-performance liquid chromatography quadrupole time-of-flight mass spectrometry method for the analysis of antidiabetic drugs in aqueous environmental samples. Journal of Chromatography B: Analytical Technologies in the Biomedical and Life Sciences 895-896: 94-101.

Mokhtar, S.U., Kulsing, C., Althakafy, J.T., Kotsos, A., Drummer, O.H. \& Marriott, P.J. 2020. Simultaneous analysis of drugs in forensic cases by liquid chromatography-high-resolution orbitrap mass spectrometry. Chromatographia 83(1): 53-64.

Namieśnik, J., Spietelun, A. \& Marcinkowski, L. 2015. Green sample preparation techniques for chromatographic determination of small organic compounds. International Journal of Chemical Engineering and Applications 6(3): 215-219.

Nannou, C.I., Kosma, C.I. \& Albanis, T.A. 2015. Occurrence of pharmaceuticals in surface waters: Analytical method development and environmental risk assessment. International Journal of Environmental Analytical Chemistry 95(13): 1242-1262.

Omran, N.H., Wagdy, H.A., Abdel-Halim, M. \& Nashar, R.M.E. 2019. Validation and application of molecularly imprinted polymers for SPE/UPLC-MS/MS detection of gemifloxacin mesylate. Chromatographia 82(11): 1617-1631.

Pizarro, C., Pérez-Del-Notario, N., Sáenz-Mateo, A. \& González-Sáiz, J.M. 2014. A simple and sensitive vortex assisted liquid-liquid microextraction method for the simultaneous determination of haloanisoles and halophenols in wines. Talanta 128: 1-8.

Radke, M. 2010. Fate of pharmaceuticals in the environment and in water treatment systems. Toxicological \& Environmental Chemistry 92(1): 209.
Selahle, S.K. \& Nomngongo, P.N. 2020. Determination of fluoroquinolones in the environmental samples using vortex assisted dispersive liquid-liquid microextraction coupled with high performance liquid chromatography. International Journal of Environmental Analytical Chemistry 100(3): 282-294.

Siddiqui, S. 2014. Depression in type 2 diabetes mellitus - A brief review. Diabetes and Metabolic Syndrome: Clinical Research and Reviews 8(1): 62-65.

Yiantzi, E., Psillakis, E., Tyrovola, K. \& Kalogerakis, N. 2010. Vortex-assisted liquid-liquid microextraction of octylphenol, nonylphenol and bisphenol-A. Talanta 80(5): 2057-2062.

Sohaib Jumaah Owaid Luhaibi \& Mazidatulakmam Miskam* School of Chemical Sciences

Universiti Sains Malaysia

11800 USM, Pulau Pinang

Malaysia

Noorfatimah Yahaya

Integrative Medicine Cluster

Advanced Medical and Dental Institute (AMDI)

Universiti Sains Malaysia

13200 Bertam, Pulau Pinang

Malaysia

Anas Alshishani

Faculty of Pharmacy

Zarqa University

13132 Zarqa

Jordan

Maizatul Najwa Jajuli

Department of Chemistry

Faculty of Science and Mathematics

Sultan Idris Education University

35900 Tanjong Malim, Perak Darul Ridzuan

Malaysia

*Corresponding author; email: mazidatul@usm.my

Received: 15 April 2020

Accepted: 1 October 2020 